\title{
Globo H-DT Vaccine OBI-833
}

National Cancer Institute

\section{Source}

National Cancer Institute. Globo H-DT Vaccine OBI-833. NCI Thesaurus. Code C119745.

A carbohydrate-based vaccine comprised of the Globo $\mathrm{H}$ hexasaccharide 1 (Globo $\mathrm{H}$ ) antigen conjug ated to DT-CRM197, a non-toxic, mutated form of diphtheria toxin (DT), with potential immunostimulating and antineoplastic activities. Upon administration of Globo H-DT vaccine OBI-833, the carbohydrate antigen Globo H may stimulate a cytotoxic T-lymphocyte (CTL) response against Globo H-expressing tumor cells, thereby decreasing tumor cell proliferation. The hexasaccharide Globo $\mathrm{H}$ is a tumor-associated antigen (TAA) commonly found on a variety of tumor cells. DT-CRM197, also called diphtheria toxin cross-reacting material 197, is used to increase the immunogenicity of the Globo $\mathrm{H}$ carbohydrate antigen. 